\title{
PROJETANDO A HUMANIDADE: \\ OBSERVAÇÕES SOBRE A EDUCAÇÃO APANJEKRA
}

\author{
PROJECTING HUMANITY: \\ OBSERVATIONS ON APANJEKRA EDUCATION
}

\author{
Bruno Nogueira Guimarães*
}

\section{Introdução}

Este artigo é o primeiro passo buscando entender os sentidos que os Apanjekra dão aos "projetos" que desenvolvem junto à população não indígena, incluindo órgãos do Estado e ONGs. Para conduzir a análise, exploro diferentes situações de minha experiência de campo, dando particular atenção para o período que passei em Porquinhos em 2013, quando comecei a escrever documentos para os Apanjekra e atendi às demandas de algumas pessoas em aprender matemática. Minha hipótese é que os "projetos" se tornaram um modo específico de relação interétnica, através dos quais os Apanjekra esperam acessar recursos exclusivos dos brancos. Para fazer um projeto funcionar, é necessário adquirir o domínio de técnicas específicas dos brancos, como a escrita e a matemática ocidental, aumentando o interesse indígena pela escola. Narrando meu envolvimento com alguns estu- dantes da Escola Municipal Moisés Canela e com as lideranças aldeãs que discutiam a produção de projetos comigo, levanto as seguintes questões: o que torna um projeto eficaz e faz com que outros sejam recusados? Como as técnicas aprendidas na escola se relacionam com as práticas indígenas? Ao discutir o local dos "projetos", tento abrir caminho para o debate do lugar ocupado pelos papéis e pela escola entre os Apanjekra.

\section{Projetando o universo}

Em 2013, minha posição em campo sofreu uma drástica mudança quando um novo coordenador assumiu a Coordenação Técnica Local Canela (Funai - Barra do Corda). Eu já estava na aldeia Porquinhos quando Renato chegou e eu me apresentei. Trocamos poucas palavras, ele perguntou sobre minha formação acadêmica (eu cursava o segundo ano do doutorado) e me

\footnotetext{
* Doutor em antropologia social (PPGAS, MN - UFRJ). Pós-doutorando em saúde coletiva pela Escola Nacional de Saúde Pública - FIOCRUZ (Rio de Janeiro/RJ/BR). brunongbh@gmail.com.
} 
informou que faria uma reunião com todas as lideranças Apanjekra sobre um assunto grave. Quis saber se eu tinha o costume de acompanhar as discussões políticas da aldeia, a que eu respondi positivamente. Muitos homens adultos já ocupavam o pátio central e, em pouco tempo, quatro professores da Escola Municipal Moisés Canela se juntaram a nós.

Já de pé, no meio da clareira e cercado pelo público, Renato se virou para mim e pediu que eu fizesse a ata da reunião. Desde minha primeira ida a campo, no primeiro semestre de 2011, eu nunca havia visto qualquer ata sobre reuniões em Porquinhos ser produzida, e os Apanjekra não pediam algo assim para mim. Renato percebeu minha surpresa e explicou a todos que, por se tratar de um tema sério envolvendo projetos da aldeia, era necessário que tudo fosse registrado no papel, para termos um documento em caso de algum problema futuro. Além disso, explicou a todos que eu era a pessoa ideal para a redação, dado que era "o mais estudado" entre os presentes.

Dispensados os docentes, iniciou-se uma outra reunião com uma nova ata, para tratar do segundo ponto que levava Renato a Porquinhos: em 2011, uma das várias associações indígenas dos Apanjekra propôs um projeto para a Secretaria de Educação do Estado do Maranhão. Com a finalidade de adquirir carros, contratar motoristas e arcar com as despesas dos deslocamentos, a associação passou a receber $R \$ 108.000$ semestrais, que deveriam ser destinados ao transporte escolar dos estudantes da aldeia. 0 objetivo era assegurar que os alunos que estivessem em seus roçados ou mesmo na cidade pudessem chegar à escola, em Porquinhos, e não serem prejudicados em seus estudos. Como, mais de um ano após o início dos aportes financeiros, nenhum carro fora adquirido, surgiram acusações e denúncias a respeito da malversação dos fundos. A aldeia cindiu. A maior parte da população estava insatisfeita e exigia que o pahí, termo que os Timbira traduzem por "chefe" ou "cacique", tomasse providências junto às autoridades estatais. Outras lideranças, porém, apoiavam a direção da associação e indicavam que alguns kupen (não indígenas) tinham desviado os recursos. Acusavam especialmente o contador, filho de uma funcionária da Secretaria Especial de Saúde Indígena (SESAI), responsável por lidar com as finanças e operações bancárias que nenhum habitante de Porquinhos dominava. Em 2013, com a formalização de denúncias junto à Secretaria de Educação por meio de um abaixo-assinado, o repasse foi suspenso.

Renato esclareceu que esta situação era ruim para toda a comunidade. 0 contador já era investigado pelo Ministério Público e não deveria mais controlar o dinheiro da associação. Seria interessante para a aldeia que os recursos do transporte escolar voltassem a Porquinhos, porém com uma gestão compartilhada dos dois grupos políticos. Ele propôs uma aliança, em que o cacique da aldeia pediria a volta do repasse enquanto a diretoria da associação convocaria eleições para um novo mandato.

A ata foi assinada pelas lideranças e entregue a Renato. 0 coordenador da CTL regressou a Barra do Corda, e eu à residência de minha família. Antes de entrar na casa, meus parentes, reunidos como de costume na frente da moradia, me perguntaram se era verdade que eu sabia fazer bons documentos dos kupen, como projetos e abaixo -assinados. Até então, eu sempre havia respondido a essa questão dizendo que nunca havia feito um "projeto", mas que poderia encaminhar as demandas dos Apanjekra à 
Funai ou ao Centro de Trabalho Indigenista, que tradicionalmente cuidavam desses assuntos. Sobre os abaixo-assinados, eu fora advertido por meu pai, em meu primeiro campo, a não me envolver. Eles tratavam de questões internas à aldeia, das quais os kupen não deveriam tomar parte. Assim, em meus períodos de campo em 2011 e 2012, os Apanjekra não se interessaram por mim para produzir seus documentos, querendo apenas que eu registrasse com fotos, vídeo e áudio suas festas, repassando depois o material a eles.

A percepção dos Apanjekra sobre mim, mudou. Aquele que deveria ser o maior especialista na produção de documentos afırmara, junto a todas as lideranças, que eu escreveria melhor do que ele. Todos sabiam que Renato havia acabado de me conhecer e não tinha lido qualquer documento já produzido por mim, mesmo porque eu não produzira nenhum até então. E ele não corrigiu nada que estava escrito: pelo contrário, em alguns momentos pediu minha opinião sobre como colocar alguma ideia no papel. Os Apanjekra, como os demais povos Timbira, se reúnem no pátio no alvorecer e no crepúsculo. Quando me dirigi pela segunda vez ao centro da aldeia naquele dia, fui cercado pelas lideranças. Queriam saber sobre minha capacidade de escrever projetos.

Tive que assegurar que não mentira para eles nos meses anteriores: de fato, eu nunca havia feito outros documentos como o que Renato me solicitou. Aquelas atas, eu expliquei, não eram projetos, eram apenas o registro do que fora concordado na reunião conduzida pelo coordenador da CTL. Me retrucaram que eram abaixo-assinados, como todas as atas feitas na aldeia. Os nomes de todas as lideranças acompanhavam as palavras nos papéis, dando poder a elas.
Renato poderia usar as atas para recuperar o repasse do transporte escolar, ou para mudar o quadro de professores da aldeia, pois aqueles eram papéis fortes. Era verdade. Nos meses seguintes, a Secretaria de Educação voltou a enviar os recursos (apesar das mudanças previstas na associação não terem acontecido, tampouco os professores-patrões deixaram seus cargos ou modo de atuação). E eu passei a receber diversos pedidos para escrever "projetos" e "abaixo-assinados" para a aldeia.

Os Apanjekra compreenderam que era uma situação nova para mim. Renato era um coordenador recém-chegado, que não me conhecia e apenas supôs que eu produziria bons papéis. Na visão dos meus hóspedes, seu palpite foi certeiro e tinha boas razões. Eu era o "mais estudado”, e o estudo dos kupen corresponde a lidar com a escrita. Como meus amigos da aldeia não me perguntavam sobre minha trajetória acadêmica e não saberiam compará-la com as dos outros não indígenas com quem tinham contato, minha escolaridade não era uma questão. Nenhum habitante de Porquinhos cursou o ensino superior - os Apanjekra mais graduados são homens que estudaram na cidade e cursaram apenas magistério, junto ao ensino médio. A EM Moisés Canela se limita ao ensino fundamental, e em 2013 possuía 14 professores: seis indígenas com a formação acima, e alguns dos demais professores com o terceiro grau completo.

Nos dias seguintes à reunião com Renato, as lideranças discutiram extensamente os projetos que eu viria a escrever. 0 primeiro foi um "projeto de amjikin", os rituais feitos ao longo do ano. Precisavam ainda decidir qual festa seria a do projeto, mas já sabiam o que deveria constar: queriam muitos cortes de pano, dezenas de quilos de miçangas, centenas de quilos de carne de boi, diversos 
calções, bastante fumo e alguns produtos alimentícios para poderem fazer festa. Me ditaram tudo o que queriam receber dos $k u$ pen, dentro de seu projeto, e pediram para eu fazer um bom documento, que todos assinariam. Quando os homens resolveram que este seria um "projeto de Pep Kahàk", um ritual marcadamente masculino, as mulheres se reuniram e disseram que eu deveria fazer um "projeto de Rãjrãj Jarkwa", a festa da laranja conduzida pelas mulheres. No pátio central, elas me ditaram todos os artigos que eu deveria incluir no documento, repetindo os pedidos do projeto dos homens.

Nesse período, uma liderança teve a ideia de fazermos um "projeto de museu", que seria como os "projetos de amjikin", só que haveria câmeras, gravadores e filmadoras, para registrar todos os rituais. Neste novo projeto, estaria prevista também a construção de um museu na aldeia, para abrigar todo o material produzido. Assim, toda vez que um kupen visitasse Porquinhos, ele poderia ir ao museu e "ver a cultura" - no caso de chegar em um momento que não houvesse festa, como me explicaram. No museu, os jovens também aprenderiam os cantos rituais e os perigos da perda dos conhecimentos especializados seriam reduzidos, já que, gravados, não desapareceriam caso um mestre falecesse antes de transmitir seu conhecimento. 0 "projeto de museu", que chegou a ser escrito e enviado ao Prêmio Itaú Cultural, previa ofıcinas de filmagem e fotografia, para que os próprios Apanjekra conduzissem o registro posterior de suas atividades.

As lideranças propuseram que eu escrevesse um "projeto de escola", para resolver os problemas enfrentados na EM Moisés Canela. Listaram tudo o que havia nas escolas das cidades e que faltava na da aldeia, de biblioteca a computadores, passando por professores presentes, ensino de nível médio, melhoria na pintura e um circuito elétrico de qualidade. Depois de discutirmos para onde encaminhar as demandas educacionais, o "projeto" foi transformado em um abaixo-assinado, enviado à Secretaria de Educação de Barra do Corda.

Ainda em 2013, as lideranças indígenas pensaram em propor um "projeto de estrada”, para melhorar as condições de trânsito entre Porquinhos e Barra do Corda. A ideia foi abandonada por conta das ameaças de aumento das invasões no território indígena. Também debateram no pátio outros projetos que não foram formulados, pensando em como aumentar a disponibilidade de remédios na aldeia e a aquisição de bens dos kupen.

Enquanto os homens mais velhos se reuniam comigo no pátio central para debater estas propostas, eu recebia visitas de pessoas interessadas em projetos não comunitários. Elas queriam que eu recuperasse os "projetos de criação", prometidos por um antigo coordenador da CTL Canela. Alguns chegaram a ser realizados. Em meados dos anos 2000, o então coordenador Francisco estimulou a fundação de diversas associações indígenas representando os "setores de roça" da TI Porquinhos, onde os corresidentes plantam seus alimentos a alguns quilômetros da aldeia. As decisões dessas associações não passam pelo pátio central, já que têm em seus membros apenas pessoas da mesma família: a associação do setor Sambaíba é composta somente pelos parentes que cultivam seu próprio alimento, na região chamada Sambaíba, como ocorre com todas as associações desse tipo. Os "projetos de criação" obteriam porcos, galinhas ou peixes, que seriam de domínio dos membros do setor. 0 mais notável destes foi o "projeto de emas" - ave criada nas 
imediações da aldeia por um dos anciãos de maior prestígio entre os funcionários da Funai. 0 plano dos indigenistas era estimular o desenvolvimento aldeão, que poderiam vender os ovos das emas ou lucrar com a reprodução do valioso animal. Em todos esses projetos, as criações foram comidas pelos criadores. Por isso, os funcionários da Funai achavam que os projetos fracassaram. Pelo mesmo motivo, os Apanjekra os consideravam um sucesso, e queriam que eu os ajudasse a conseguir mais.

Nos três anos seguintes, o tema dos projetos foi recorrente em meus campos em Porquinhos. 0 afã inicial diminuiu: nenhuma das nossas tentativas iniciais deu certo. 0 "projeto de museu" ficou entre os primeiros excedentes do Itaú Cultural e não foi financiado; o abaixo-assinado pela escola não foi respondido pela secretaria de educação; os "projetos de criação" não foram sequer propostos, em parte porque nem eu, nem Renato, sabíamos como fazê-los e, em parte, porque as associações dos setores de roça que pesquisei estavam com pendências nas prestações de contas, algumas com dívidas em bancos. Mesmo os professores-patrões permaneceram em seus cargos, a despeito da reunião conduzida por Renato e da ata escrita por mim, abandonando posteriormente as suas funções como docentes por empregos mais lucrativos na cidade. Ainda que tudo isso indicasse que meus papéis não eram tão potentes como as lideranças imaginaram, estive no centro da produção de outros documentos. Em 2015, escrevi alguns projetos para financiamento de rituais, que foram apoiados pelo Museu do Índio em 2016. E arremedos dos diversos textos que produzi foram utilizados na proposta do Plano de Gestão Territorial e Ambiental da TI Porquinhos, também em 2016.
Apesar de os Apanjekra falarem sobre os projetos desde meu primeiro campo, em 2011, foi apenas a partir de 2013 que notei como eles constituíam um idioma particular da relação interétnica. Como ocorre com diversos termos em português apropriados pelos indígenas, a ideia dos Apanjekra sobre os "projetos" corresponde apenas parcialmente àquilo que nós, kupen, concebemos como sendo um projeto. De tal modo que é comum aos agentes indigenistas corrigirem os Apanjekra, explicando que algo que eles pleiteiam não pode ser incluído em um projeto, ou que não existe projeto sobre aquilo. 0 sentido que os Apanjekra dão aos projetos é bem mais amplo. Em 2015, a aldeia debateu extensamente o que chamaram de "projeto de Minha Casa, Minha Vida": as administrações municipais locais ofereceram às lideranças indígenas a inclusão da população de Porquinhos na política habitacional, prometendo a construção de casas na aldeia para todos os moradores. 0 ânimo dos Apanjekra era enorme, pois os kupen reformariam ou reconstruiriam todas as residências que não estivessem novas, poupando muito trabalho e ajudando, particularmente, os mais idosos que precisavam contar com o favor de parentes para realizar o serviço. Quando descobriram que as casas não seriam construídas no modelo tradicional, e sim como as habitações dos brancos, resolveram não descartar a participação na política pública: proporiam seu próprio "projeto de Minha Casa, Minha Vida”, explicando para os kupen como as casas timbira eram construídas, em qual região da chapada se encontrariam as palmáceas que fariam a cobertura do telhado e quais eram as melhores madeiras para a sustentação da casa. A ideia só foi abandonada após a negativa das administrações em acolher as propostas indígenas e repassá-las às empreiteiras. 
"Projeto de amjikin", "projeto de museu", "projeto de criação” e "projeto de Minha Casa, Minha Vida” foram apenas algumas ocorrências que utilizei para exemplificar a vasta gama de aplicações que os Apanjekra dão ao termo, que confunde funcionários públicos e pesquisadores. Existem características comuns a todos os projetos. Eles só ocorrem na relação entre os indígenas e os kupen, não havendo projeto apenas entre os Apanjekra. Todo projeto é escrito para que algum kupen ou órgão kupen o receba. A finalidade dos projetos, a partir daí, é obter para os proponentes algo a que eles não têm acesso, ou a que o acesso é difícil. Como se vê, a "lista de desejos" dos projetos se concentra em bens ou em serviços dos kupen. Por fim, a produção dos projetos requer o domínio de tecnologias estrangeiras, a escrita e a contagem kupen, e o refinamento de seu exercício.

\section{Educando como os brancos}

Os professores que participaram da reunião com Renato eram criticados pelos Apanjekra por não cumprirem suas obrigações de docência e, em vez disso, se dedicarem à agiotagem. 0 que torna este caso curioso é que os Apanjekra raramente falam mal de um patrão para alguém de fora da aldeia, por duas razões. Primeiro, porque a intromissão de terceiros na relação de um patrão com seu "freguês" ou "cliente" pode dificultar o acesso deste último às mercadorias kupen que deseja obter. 0 patrão mantém os titulares dos benefícios sociais endividados e em uma relação de dependência, pois ele é necessário para mediar a relação com os bancos e o comércio, dado que a maioria dos indígenas não sabe ler ou utilizar a matemática dos kupen. Os patrões também são os principais responsáveis pelo trânsito entre Porquinhos e Barra do Corda, além de oferecerem o adiantamento de parte do valor dos saques dos benefícios. A não ser quando um patrão se torna abusivo em suas cobranças, não oferecendo mais nada aos seus fregueses enquanto estes estão endividados (o que pode significar longos períodos de fome na cidade, sem transporte e dinheiro para se alimentar), os Apanjekra não os denunciam e evitam envolver quaisquer autoridades.

0 segundo motivo para a não exposição dos agiotas está na visão que os Apanjekra possuem dos kupen. Concebendo estes como iminentemente sovinas, esperam que a maioria dos não indígenas cobre por algum ato que possa beneficiar outra pessoa, como fazem os patrões. Os kupen rejeitam a produção dos laços de parentesco, não praticando a corresidência ou a comensalidade. São figuras antissociais, que demonstram interesse apenas por suas próprias coisas, como em sua avidez pelo dinheiro e no desprezo pelos artigos indígenas. Os raros kupen que buscam viver junto aos Apanjekra, compartilhando da vida destes, precisam ser educados, pois não sabem ainda viver como gente: não entendem o que devem dar ou como devem dar, tampouco sabem o que lhes é permitido esperar e receber. Aprender a compartilhar está, para os Jê setentrionais, no cerne do processo de fabricação do parentesco por meio de uma assimilação corporal (COELHO DE SOUZA, 2002, 2004) e da produção de uma intersubjetividade (EWART, 2005, 2014) que, ao implicar o reconhecimento da necessidade dos demais, indica o comportamento apropriado frente àqueles com os quais se compartilha a vida.

0 que despertou a animosidade das lideranças frente aos professores-patrões foi a contradição da atividade que estes exer- 
ciam. Os Apanjekra veem a escola como um espaço onde poderiam aprender as técnicas dos kupen, descobrindo as formas de acessar os domínios destes sem precisar de intermediários, como os agiotas. Quando os kupen se empenham em explicar aos indígenas a importância de sua educação formal, destacam a nova condição assumida pelos formados. Ao fim dos estudos, o aluno saberá ler as bulas dos remédios e os documentos dos brancos, usar os bancos, poderá trabalhar nas instituições kupen de educação e saúde, dentre outras possibilidades que são prometidas aos Apanjekra. Negar o ensino e se beneficiar dessa negação duplica a mesquinharia esperada dos kupen. Os professores deveriam escolher entre não dar aulas na aldeia (como a maioria dos professores não indígenas fazia, sem problemas mais graves) ou serem patrões (como muitos dos kupen não professores que frequentavam Porquinhos). Tanto professores ausentes quanto agiotas eram criticados dentro da aldeia, mas nunca denunciados. Ser ambos ultrapassava o limite do aceitável.

Nas conversas que tive com os Apanjekra sobre a escola, três eram os grandes interesses que eles demonstravam. Queriam aprender a ler, a escrever e a contar como os kupen. É importante distinguir a leitura da escrita, já que elas são concebidas e experimentadas como atividades diferentes. Para começar, o número de pessoas capaz de ler na aldeia é significativamente maior do que a quantidade de pessoas capaz de escrever. Embora não haja um censo a esse respeito, em praticamente qualquer residência em Porquinhos é possível encontrar alguma pessoa mais jovem que lê em português e em timbira (toda a aldeia é bilíngue e tem a língua timbira como primeiro idioma). Mas, além dos professores indígenas, poucos es- crevem, qualquer que seja a língua. Ler e escrever também são consideradas técnicas distintas: o material utilizado para ensinar os Apanjekra a ler não tem nenhuma semelhança com os textos que eles querem produzir. Todo o vocabulário especializado empregado pelos kupen nas administrações municipais, nos órgãos e ONGs indigenistas, nas políticas públicas ou nos bancos, não está presente nas escolas.

Após eu ser descoberto como um "projetista”, o marido de uma de minhas irmãs me procurou, pedindo ajuda para aprender matemática. À época, um dos professores -patrões era o responsável pela matéria. Apesar de estar matriculado no penúltimo ano do ensino fundamental, Guilherme dominava apenas somas e subtrações simples, envolvendo números com somente um dígito. Em alguns dias, estava acertando o resultado de adições com vários dígitos, e então passaram a estudar outras operações matemáticas. Minhas irmãs e meu outro cunhado começaram a participar das "aulas”, ao redor da fogueira na frente de nossa casa. Enquanto eu passava as lições nos cadernos dos estudantes, de acordo com o conhecimento de cada um, meu pai queria ver qual deles concluiria os cálculos primeiro. 0 vencedor, brincava ele, ganharia um presente: eu teria que comprar refrigerante e biscoitos na venda da aldeia para dar a quem me ajudou com minhas contas, da mesma forma que eles pagam os patrões por assistirem eles.

Outras pessoas começaram a me visitar, pedindo que eu também lhes ensinasse. Como na maior parte do mês a escola estava ociosa, decidiram que eu daria aulas ali. Não havia periodicidade definida: os interessados me procuravam e diziam que queriam estudar. Em vinte dias, fomos onze vezes à escola. As aulas tinham em 
torno de 6 alunos, em estágios distintos de aprendizado, e nem sempre os mesmos alunos compareciam (13 pessoas diferentes frequentaram esses encontros). Desde o início, eu tentei não reproduzir o formato da educação do ocidente moderno: sugeri que as aulas não ocorressem na escola (que fica na parte externa do círculo periférico da aldeia) e sim em ambientes aldeões que eles escolhessem. Também busquei dar exemplos que fossem parte da vida dos alunos, e pedir que os próprios me trouxessem exemplos do cotidiano indígena. 0 espaço da escola era marcadamente kupen, e eu esperava contornar isso, para evitar a ideia de que a matemática é privilégio do Ocidente. Minha proposta inclusiva era falar sobre a relação entre valores e quantidades dentro da aldeia, para não dissociar o conhecimento matemático do cotidiano indígena. Explicar a divisão como a partilha de alimentos que ocorre na comensalidade demonstraria como os Apanjekra já tem pleno domínio daquelas operações. Nenhuma dessas tentativas vingou.

A proposta de ministrar aulas no ambiente indigena passava uma mensagem contraditória: ao contrário das correntes educacionais que defendem a adaptação do conteúdo da matéria à realidade dos estudantes, os Apanjekra querem o conhecimento kupen justamente por ele ser um conhecimento estrangeiro, que trata de coisas que não são próprias à vida indígena. A escola não é vista pelos alunos como um espaço de formação pessoal. Antes, é um ambiente específico do aprendizado de técnicas centrais na relação com os brancos. Se me era frustrante passar listas de exercícios para os alunos resolverem, este era o pedido que eu sempre recebia. Nos onze encontros, alguém que estava com dificuldades em realizar multiplicações me pedia ajuda e uma lista de cálculos, que eu produzia após explicar a lógica da operação e como a realizar. Eu corrigiria a tarefa e passaria uma nova, atendendo à demanda do aluno.

Preocupado em encontrar os melhores termos para traduzir o conteúdo daquelas operações, eu não percebi que, para aprender uma técnica os alunos achavam necessário aprender sua forma - não apenas o que se sabe, mas "como se sabe" (GALLOIS, 2014). Era claro, para mim e para eles, que eles sabiam dividir as coisas na aldeia. Quando levam animais abatidos para o pátio central, na véspera de um grande ritual, em alguns minutos esquartejam e distribuem a carne entre dezenas de pessoas representando as cem casas que existem no círculo periférico. Aliás, se veem mais capazes de dividir do que os kupen (GUIMARÃES, 2017). Mas o que os interessa é como os kupen fazem a divisão (e outras operações matemáticas) no papel, em seus documentos, nos procedimentos contábeis e bancários que os Apanjekra precisam lidar. Além disso, como uma das alunas me explicou, a divisão deles não é a mesma dos brancos. Quando perguntei: "se você tem 14 laranjas e vai dá-las às suas duas irmãs, quantas cada uma vai receber?”, ela me respondeu: "Acho que a mais velha vai receber mais, porque tem mais filhos. Mas se minha irmã mais nova tiver fome, eu cuido dela e dou todas as laranjas para ela, porque ela ainda é muito pequena”. As divisões dificilmente resultarão em quantidades iguais para pessoas diferentes quando as necessidades de cada uma são observadas. A atenção às demandas específicas, que sequer precisam ser enunciadas, é o índice da intersubjetividade que caracteriza a humanidade e o parentesco (EWART, 2005, 2014). Distribuir 7 laranjas para cada 
irmã, sem se importar com qual precisaria de mais alimento, corresponde ao cálculo dos brancos, mas não ao modo apanjekra de se relacionar com os parentes.

Se os processos que fundamentam as divisões dos Apanjekra e dos kupen não são equivalentes, e se não se tratava de transpor o conteúdo kupen para a forma indígena, o que os alunos queriam fazer, naqueles encontros em que recebiam listas e mais listas de exercícios? As técnicas aprendidas na escola fazem parte de um idioma e, em vez de entender o que os kupen dizem em seu idioma particular, os Apanjekra querem aprender a falar a mesma língua. A aproximação da escola com a prática xamânica é clara: ambas oferecem vias para se relacionar com uma humanidade diferente da sua, através do aprendizado de outro idioma que será a base da relação. Este aprendizado é visto como um acréscimo de capacidades, que permitem ao iniciado o trânsito e a atuação em ambientes que, antes, se mostravam inacessíveis ou perigosos.

A analogia entre a educação formal, a atividade xamânica e outras formas de conhecimento que têm na alteridade o seu ponto de partida não é nova. Em diálogo com o trabalho de Lagrou (1998), Ingrid Weber (2006) demonstra como a escrita, para os Huni Kuin ${ }^{1}$, está associada ao aprendizado da tecelagem gráfica (kene): ambas são habilidades que precisam ser desenvolvidas na relação do corpo com um ambiente (INGOLD, 2000) ${ }^{2}$ e exigem um contexto específico para o seu aprendiza- do, no qual um especialista irá transmitir seus conhecimentos ao iniciante. Para os Huni Kuin, bem como para os Apanjekra, o contexto de transmissão é onde o especialista se apresenta enquanto especialista. No caso dos kene, é a sociabilidade feminina, em que as mulheres mais velhas tecem na companhia das gerações mais novas. No caso da escrita, é a escola. Assim como a jovem segue os padrões e as técnicas de sua mãe ao começar a tecer os kene, o aluno repete, em seu caderno, tudo o que o professor escreve no quadro.

Meus interlocutores narravam o aprendizado de suas habilidades a partir da relação com outras pessoas mais velhas. Antônio, um dos maiores especialistas rituais de Porquinhos, me disse que se tornou um bom cantor porque sempre seguia o irmão de sua mãe nas festas, outro renomado especialista. "Quando ia ter amjikin, eu ficava bem perto dele, e o acompanhava, ficava escutando sempre”. A preocupação de Antônio é que os jovens não estariam acompanhando os cantores das festas, e a quantidade de vozes novas surgindo é cada vez menor. Ele diz que, quando o cantor está no pátio puxando músicas para o coral feminino repetir, as crianças deveriam estar atrás dele, "como um rabinho, pulando e cantando também”. Ele reclama do desânimo e da vergonha dos mais jovens em participar: "não tem problema errar, porque ainda não sabe. Se não acompanhar o cantor, nunca vai ser cantor”. Bons corredores e caçadores também re-

1. Os Huni Kuin, também conhecidos como Kaxinawá, são um povo falante de língua Pano que habitam a região amazônica na divisa do Brasil com o Peru, próximos ao alto curso dos rios Purus e Curanjá.

2. Ou, de forma mais clara, sem dissociar corpo e mente. 0 desenvolvimento de uma habilidade (skill, no vocabulário de INGOLD, 2000) não pertence apenas ao domínio do intelecto do indivíduo, e sim ao campo de relações que o "corpo-organismo" estabelece com o ambiente. 
putam suas capacidades ao convívio com parentes que eram exímios no que faziam. A aquisição de todas essas capacidades está vinculada à noção nativa de "acompanhar”, que designa a aproximação de dois corpos que passam a se influenciar mutuamente. 0 companheiro (ikwynõ) está em direta oposição ao amigo formal

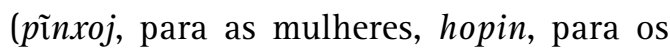
homens) - este, marcado por relações de evitação e cooperação cerimonial. No caso de necessidade, o ikwynõ é a pessoa fora do campo do parentesco a quem se pode recorrer. As caçadas cotidianas, que se opõem às rituais por serem marcadamente individuais, frequentemente são realizadas junto ao companheiro. Com ele, não é necessário ter paham, o "respeito / vergonha" que caracteriza o comportamento frente ao amigo formal.

Como já notava Carneiro da Cunha (2009a), com o companheiro se estabelece uma relação de semelhança ou de simultaneidade. Para os Krahô, são companheiras as crianças que nascem no mesmo dia, os jovens que chefiam os grupos rituais do mesmo Pep Kahàk, as mulheres que participam das festas nas mesmas posições, sempre em pares. É, portanto, aquele que faz o mesmo que eu faço, quando eu faço: “o companheiro é a ação ou função simultânea, aquele que me espelha em minhas obras e no qual eu me reconheço e me assumo enquanto homem agindo" (CUNHA, 2009a, p. 57). Mas o companheirismo não é dado: ele é fruto da aproximação de duas pessoas distintas em uma mesma situação, o que implica que pertençam à mesma classe de idade. A noção de acompanhar, portanto, engloba a categoria de companheiro, já que se pode acompanhar os mais velhos para compartilhar das capacidades destes.
0 aprendizado como acompanhamento já foi notado em outros contextos etnográficos e também é desenvolvido por Weber (2006) para os Huni Kuin. Este aprendizado remete à noção pan-amazônica de assemelhamento, que postula que a similaridade (o parentesco) é construída a partir de uma ação intencional e processual sobre uma forma estrangeira (VILAÇA, 2002), que é gradualmente incorporada à cartografia social do corpo em questão (VIVEIROS DE CASTR0, 2002a; 200b). Mesmo a aquisição de capacidades marcadamente episódicas pode ser formulada em termos processuais. Marques, um grande xamã apanjekra, me contava do convívio com seu nominador (irmão de sua mãe): "eu era pequeno, ainda não sabia nada. Ficava ali, com todo mundo, mas gostava muito do meu keti, por isso sempre acompanhava ele, ia no mato junto, via ele fazer as coisas. Ele colocava a mão na árvore e a mão atravessava. Eu não entendia aquilo, mas queria saber também, então acompanhava ele, ouvia ele falando com mekaron que eu não via, nem entendia conversa. Aí, quando eu cresci, mekaron apareceu para mim também e falou comigo". Em outras situações, Marques me relatara a aquisição de seus poderes de xamã a partir do encontro com espíritos de outras espécies, que quase o mataram para o capturar e fazer dele parente. Nestas situações, teria aprendido a se comunicar com os espíritos predadores. Mas foi a partir do convívio com seu tio xamã que seu corpo se preparou para ver os espíritos que as pessoas comuns não veem.

Para dominar as técnicas kupen, os Apanjekra buscam os ambientes em que os especialistas não indígenas revelam suas capacidades. Criar este contexto é a função da escola. Mas, por que as técnicas dos $k u$ pen são tão diferentes da dos Apanjekra? 


\section{Considerações finais: a eficácia do papel}

A escola oferece as ferramentas para que os Apanjekra consigam compreender o universo kupen e produzir os documentos que estes exigem para atender às demandas indígenas. Como se vê em outros contextos etnográficos, há uma relação direta entre o interesse pela escrita e o interesse pelos projetos (ESCOBAR; GALVÃO; GOMES, 2017). Assim como no caso dos Apanjekra, a escola deve ser percebida como um elemento da relação com os não indígenas, que extrai seu sentido desta relação.

À guisa de conclusão, gostaria de perguntar: o que torna um papel um "bom documento", e qual a diferença entre um projeto que é aprovado e um que é reprovado? Como minhas primeiras tentativas fracassaram, tive que dar as más notícias: o "projeto de museu" não seria financiado; não houve resposta da secretaria de educação sobre o abaixo-assinado da escola; e por aí em diante. Isto levava a grandes discussões sobre as respostas aos nossos documentos, ou mesmo à ausência delas. Indicar que os editais a que concorríamos não contemplavam todos os participantes, não alterava as questões levantadas pelos meus interlocutores. Os habitantes de Porquinhos, contudo, não partiam de uma noção de escassez de bens materiais (SAHLINS, 1972), razão pela qual a recusa em apoiar seus projetos era vista como uma decisão intencional, e não mero resultado da competição por um recurso limitado. Nosso projeto não podia ser bom e não ser aprovado apenas porque havia outro melhor. 0 que definia que o outro era melhor? Se os kupen que receberam vários projetos bons só tinham dinheiro para acolher alguns, porque não buscavam mais dinheiro para apoiar os outros projetos que também julgaram importantes? E por que não dividir os recursos de que dispunham entre todos os bons projetos?

É a visão corrente na aldeia de que os $k u$ pen escrevem por não terem memória. Da mesma forma que os Apanjekra falam, ouvem e veem, os brancos anotam, gravam e leem. Os índios timbira compreendem o que lhes é transmitido e por isso guardam consigo o conhecimento - como se indicou com a noção de acompanhamento, as técnicas e capacidades são assemelhadas, são um processo que ocorre no corpo. Como os kupen não sabem fazer parentes, dado seu comportamento sovina, também não têm memória. Assim, precisam aprender tudo sozinhos, apenas observando o papel. É por esse motivo que os Apanjekra dependem dos projetos: o documento é o idioma da relação interétnica. Os Timbira dizem que "kupen tem cabeça de papel” e “kupen briga com papel”. A crítica da relação entre memória (indígena) e documentação (branca) se torna ainda mais saliente nos contextos de disputas judiciais, como na demarcação de terras ou acesso à saúde pública (GUERRA, 2016). Nestes casos, as duas formas de conhecer o mundo se opõem, e os indígenas precisam das armas do inimigo para combatê-lo, como o xamã que precisa falar a língua dos mekaron para salvar um enfermo.

Se estabelecemos uma analogia entre o xamanismo e a escrita, ela encontra seu limite na crítica que Davi Kopenawa faz à incapacidade dos brancos de sonhar com os espíritos, em completo acordo com o problema da memória levantado pelos Apanjekra:

[0 pensamento dos xamãs] guarda as palavras do que viram sem ter de escrevê-las. Os brancos, ao contrário, não param de fixar seu olhar sobre os desenhos de suas falas colados em pele de papel e de fazê-los circular entre eles. Desse modo, estudam apenas 
seu próprio pensamento e, assim, só conhecem o que já está dentro deles mesmos. (...) Por manterem a mente cravada em seus próprios rastros, os brancos ignoram os dizeres distantes de outras gentes e lugares (KOPENAWA; ALBERT, 2015, p. 455).

Em outro trabalho (GUIMARÃES, 2017), apontei como a causa de uma ação de dádiva estava localizada na memória que uma pessoa possui de outra. Quando as mulheres fazem adornos de miçangas e os entregam para alguma pessoa, assume-se que era a imagem desta pessoa que ela tinha em mente enquanto tramava as contas de vidro. Da mesma forma, quando os homens viajam à cidade e retornam com presentes, o fazem por terem "lembrado sempre" de quem os irá receber. Não regressar com algo para um membro da família é uma ofensa grave: o esquecimento indica um distanciamento do campo do parentesco. 0 ciclo de dádivas opera com um presente incorporando a imagem do doador, que passa a acompanhar quem o recebe e se torna parte da memória desta pessoa, levando-a a retribuir. Os Apanjekra explicam essa influência que uma pessoa exerce sobre outra a partir da noção de "saudade", em que a imagem do futuro receptor se torna uma lembrança positiva recorrente. 0 doador, assim, acompanha o receptor e participa de suas ações.

Como os kupen têm sua memória voltada para eles próprios, são sovinas. Ao discutir os projetos que não foram aprovados, um tema era comum: os brancos "se esqueceram” deles. Na relação interétnica, o esquecimento é constantemente evocado: pesquisadores que visitam a aldeia e nunca mais retornam; funcionários públicos locais que não retribuem, na cidade, a hospitalidade que receberam na aldeia; políticos e admi- nistradores que nunca cumprem as promessas feitas às lideranças; dentre outras situações em que a memória afetiva construída em Porquinhos é logo abandonada pelos brancos que voltam aos seus domínios. Os projetos surgem como uma forma de reinserir os Apanjekra no universo autorreferenciado kupen. Como os Apanjekra não aparecerão mais na memória evanescente dos brancos, eles surgirão nos papéis lidos pelos kupen. Trata-se, portanto, de adaptar a teoria da influência nativa à mnemotécnica estrangeira, tornando a imagem dos habitantes de Porquinhos novamente presente. É nesse sentido que os Apanjekra insistem que um documento bom deve ter o maior número de nomes possíveis, "dando força” ao papel. Traduzem a presença das lideranças nas reuniões do pátio em uma longa lista de nomes entregues às autoridades dos brancos. Também está aí a razão de insistirem que os projetos apresentem diversas fotografias de Porquinhos, imagem das pessoas em festa, para mostrar que “ainda estão na 'cultura”.

Esta menção final à "cultura com aspas” não é trivial (CARNEIRO DA CUNHA, 2009b). A partir do que foi exposto aqui, gostaria de sugerir que ocorre com os "projetos" algo distinto do que acontece com a “cultura”. Para esta, a apropriação indígena do termo se refere a um uso pragmático de elementos de um conceito mais amplo, a cultura sem aspas. A "cultura” aparece, assim, tanto como uma objetivação da cultura, como um "metadiscurso reflexivo sobre a cultura" (CARNEIRO DA CUNHA, 2009b, p. 373). 0 que os Apanjekra postulam é que, ao contrário, o "projeto" dos kupen é um caso particular de uma lógica de projetos mais ampla, fundada no problema da memória e da educação, que os motiva a propor projetos, abaixo-assinados, atas e 
outros documentos para lidar com as demandas que possuem no contexto do contato interétnico.

\section{Referências}

CARNEIRO DA CUNHA, M. De amigos formais e companheiros. In: Cultura com aspas e outros ensaios. São Paulo: Cosac Naify, 2009a, p. 51-58.

"Cultura" e cultura: conhecimentos tradicionais e direitos intelectuais". In: Cultu-

ra com aspas e outros ensaios. São Paulo: Cosac Naify, 2009a, 2009b, p. 311-373.

COELHO DE SOUZA, M. S. 0 traço e o círculo: o conceito de parentesco entre os Jê e seus antropólogos. 2002. 668f. Tese (Doutorado em Antropologia Social) - PPGAS, Museu Nacional, Universidade Federal do Rio de Janeiro, Rio de Janeiro, 2002.

Parentes de sangue: incesto, substância e relação no pensamento timbira. Mana - Estudos em Antropologia Social, v. 10, n.1, p. 25-60, 2004.

ESCOBAR, S., GALVÃO, A.; GOMES, A. Cultura do escrito nas associações e projetos sociais indigenas. Revista Brasileira de Educação, v. 22, n. 68, p. 231-253, 2017.

EWART, E. Fazendo pessoas e fazendo roças entre os panará do Brasil central. Revista de Antropologia, v. 48, n.1, p. 9-35, 2005.

Space and society in Central Brazil: a Paraná Ethnography. London: Bloomsbury. 2013.

GALLOIS, D. A escola como problema: algumas posições. In: CARNEIRO DA CUNHA, M.; CESARINO, P. (Orgs.), Políticas culturais e povos indigenas, p. 509-517, 2014.

GUERRA, M. Aukê e a briga de papel: ensina o mehin como o kupen faz. 2016. 144f. Tese (Doutorado em Antropologia Social) - PPGAS, Universidade de São Paulo, São Paulo, São Paulo, 2016.

GUIMARÃES, B. O outro lado da moeda: dos benefícios sociais dos brancos ao parentesco dos Apanjekra. 2017. Tese (Doutorado em Antropolo- gia Social) - Museu Nacional, Universidade Federal do Rio de Janeiro, Rio de Janeiro, 2017.

INGOLD, T. The Perception of the Environment: essays in livelihood, dwelling and skill. London; New York: Routledge. 2000.

KOPENAWA, D. Et ALBERT, B. A queda do céu: palavras de um xamã yanomami. São Paulo: Companhia das Letras, 2015.

LAGROU, E. M. Caminhos, duplos e corpos: uma abordagem perspectivista da identidade e alteridade entre os Kaxinawá. 1998. 303f. Tese (Doutorado em Antropologia Social) - PPGAS, Universidade de São Paulo, São Paulo, 1998.

SAHLINS, M. Stone Age Economics. Chicago; New York: Aldine, Atherton Inc. 1972.

VILAÇA, A. Making kin out of others in Amazonia. The Journal of the Royal Anthropological Institute, v. 8, n. 2, p. 347-365, 2002.

VIVEIROS DE CASTRO, E. 0 problema da afinidade na Amazônia". In: . A inconstância da alma selvagem e outros ensaios de antropologia. São Paulo: Cosac Naify, 2002a, p. 87-180. . Atualização contra-efetuação do virtual: o processo do parentesco. In: A inconstância da alma selvagem e outros ensaios de antropologia. São Paulo: Cosac Naify, 2002b, p. 401-55. WEBER, I. Um copo de cultura: os Huni Kuin (Kaxinawá) do rio Humaitá e a escola. Rio Branco: EDUFAC, 2006. 
RESUMO

A partir da análise da produção de documentos na aldeia e do envolvimento indígena na escola municipal na aldeia Porquinhos, questiono como os projetos de desenvolvimento se relacionam com aspectos mais amplos da percepção que os Apanjekra têm da população não indígena, compreendendo o Estado, o mercado e as políticas públicas. 0 aprendizado escolar formal está ligado à aquisição de qualidades necessárias para se relacionar com os não indígenas. Minha hipótese é que os "projetos" fazem parte do idioma das relações com os colonizadores, tratando das diferenças da memória e de princípios éticos que diferem indígenas e "brancos" nos processos de produção do parentesco e da vida coletiva.

\section{PALAVRAS-CHAVE}

Etnologia. Timbira. Canela Apanjekra. Projetos de desenvolvimento. Educação escolar.

\section{ABSTRACT}

Throughout the analysis of document production in the village and the indigenous involvement with the school in Porquinhos village, I ask how the development projects relate with broader aspects of the perception the Apanjekra people have about the non-indigenous population, comprehending the State, the Market and public policies. Formal educational learning is linked to the acquisition of qualities necessary to the relation with the non-indigenous people. My hypothesis is that the "projects" are part of the interethnic idiom, dealing with the differences of memory and ethical principles that differ "white folk" and indigenous people regarding their process of making kinship and collective life.

\section{KEYWORDS}

Ethnology. Timbira People. Canela Apanjekra People. Development Projects. Formal Education. 